\title{
Correction to: Informal payments for inpatient health care in post-health transformation plan period: evidence from Iran
}

\author{
Leila Doshmangir ${ }^{1}$, Haniye Sadat Sajadi ${ }^{2 *}$, Maryam Ghiasipour ${ }^{3}$, Ali Aboutorabii and Vladimir Sergeevich Gordeev ${ }^{5,6}$
}

\section{Correction to: BMC Public Health 20, 539 (2020) https://doi.org/10.1186/s12889-020-8432-3}

The ethics statement in this article [1] incorrectly states that the approval for this study was granted by the ethics committee of IR Iran's National Institute for Health Research (approved No: 241/M/93195). However, the ethics committee did not exist at the time this proposal was sent to NIHR, and the study was approved by the Research Council of NIHR (Approval No: 241/M/ 93195"). When this error came to light, the authors sought to obtain retrospective ethical approval from the ethics committee. The NIHR responded that obtaining ethical approval retrospectively is not possible and not necessary, especially, since there was no separate Ethics committee at that time. Furthermore, the study was already approved to be conducted by the Research Council, after taking into account all issues, including ethical considerations. Given the non-invasive nature of the study, the Editor and Publisher have decided to take no further action.

\begin{abstract}
Author details
${ }^{1}$ Social Determinants of Health Research Center, Tabriz Health Services Management Research Center, Iranian Center of Excellence in Health Management, School of Management and Medical Informatics, Tabriz University of Medical Sciences, Tabriz, Iran. ${ }^{2}$ Knowledge Utilization Research Center, University Research and Development Center, Tehran University of Medical Sciences, Tehran, Iran. ${ }^{3}$ Department of Health Management and Economics, School of Public Health, Tehran University of Medical Sciences, Tehran, Iran. ${ }^{4}$ School of Management and Medical Informatics, Iran University of Medical Sciences, Tehran, Iran. ${ }^{5}$ Department of Infectious Disease Epidemiology, The London School of Hygiene \& Tropical Medicine, Keppel Street, London WC1E 7HT, UK. ${ }^{6}$ Institute of Population Health Sciences, Queen Mary University of London, Mile End Road, London E1 4NS, UK.
\end{abstract}

Published online: 25 May 2020

\section{Reference}

1. Doshmangir $L$, et al. Informal payments for inpatient health care in posthealth transformation plan period: evidence from Iran. BMC Public Health. 2020;20:539. https://doi.org/10.1186/s12889-020-8432-3.

* Correspondence: hsajjadi@tums.ac.ir

${ }^{2}$ Knowledge Utilization Research Center, University Research and Development Center, Tehran University of Medical Sciences, Tehran, Iran

Full list of author information is available at the end of the article

C C The Author(s). 2020 Open Access This article is licensed under a Creative Commons Attribution 4.0 International License, which permits use, sharing, adaptation, distribution and reproduction in any medium or format, as long as you give appropriate credit to the original author(s) and the source, provide a link to the Creative Commons licence, and indicate if changes were made. The images or other third party material in this article are included in the article's Creative Commons licence, unless indicated otherwise in a credit line to the material. If material is not included in the article's Creative Commons licence and your intended use is not permitted by statutory regulation or exceeds the permitted use, you will need to obtain permission directly from the copyright holder. To view a copy of this licence, visit http://creativecommons.org/licenses/by/4.0/ The Creative Commons Public Domain Dedication waiver (http://creativecommons.org/publicdomain/zero/1.0/) applies to the data made available in this article, unless otherwise stated in a credit line to the data. 